\title{
EFFECTIVENESS OF POST-STROKE SOCIAL REHABILITATION IN PATIENTS WITH MODERATE IMPAIRMENTS
}

Khramov V, Kogaeva KP $\bowtie$, Arkhipova LU, Alekseeva VO, Lukyanova MI

Saratov State Medical University, Saratov, Moscow

The importance of post-stroke rehabilitation cannot be overestimated. The aim of this study was to assess the effectiveness of a standardized post-stroke rehabilitation program for patients with moderate impairments. A total of 122 stroke survivors participated in the study. Group 1 (the comparison group) consisted of 59 patients undergoing standard rehabilitation. Group 2 (the main group) consisted of 63 patients participating in a specially designed social rehabilitation program. The functional, cognitive, psychological and emotional states and the level of social activity were monitored for 6 months. Group 2 demonstrated more pronounced improvement than group 1 after 6 month of follow-up, confirmed by higher Rivermead $(p=0.011)$ and SS-QOL ( $p<0.05$ ) scores and lower DASH and Beck scores ( $p=0.015$ and $p<0.001$, respectively). In both groups, MMSE (cognitive function) scores slightly increased, but the differences between the groups were insignificant. The proposed post-stroke rehabilitation program is effective in helping patients regain their independence and improve social adaptation. The scales and scores used in the study, especially DASH and SS-QOL, are sensitive to changes in the functional state of stroke survivors with moderate impairments.

Keywords: stroke, rehabilitation, social functioning assessment, cognitive status, physical activity, neurological status, quality of life

Author contributions: Khramov W planned the study and wrote the manuscript; Kogaeva KP planned and conducted the study and wrote the manuscript; Arkhipova LU reviewed the literature and interpreted the obtained data; Alekseeva VO, Lukyanova MI performed statistical analysis.

Compliance with ethical standards: the study was approved by the Ethics Committee of Saratov State Medical University (Protocol № 1 dated September 1 , 2020). All participants gave informed consent to participate in the study.

$\triangle$ Correspondence should be addressed: Ksenia P. Kogaeva

Krasnaya, 69, Kamyshin, 403873; drkogan100@mail.ru

Received: 25.02.2021 Accepted: 18.03.2021 Published online: 31.03.2021

DOI: $10.24075 /$ brsmu.2021.012

\section{ЭФФЕКТИВНОСТЬ МЕДИКО-СОЦИАЛЬНОЙ РЕАБИЛИТАЦИИ ПОСТИНСУЛЬТНЫХ ПАЦИЕНТОВ С НАРУШЕНИЯМИ СРЕДНЕЙ СТЕПЕНИ ТЯЖЕСТИ}

\author{
В. В. Храмов, К. П. Когаева
}

Саратовский государственный медицинский университет имени В. И. Разумовского, Саратов, Россия

\begin{abstract}
На сегодняшний день остается несомненной актуальность реабилитационных мероприятий у пациентов, перенесших острые нарушения мозгового кровообращения. Целью работы было оценить эффективность стандартизированной медико-социальной программы реабилитации постинсультных пациентов с нарушениями средней степени тяжести. В исследовании участвовало две группы пациентов (всего 122 человека), перенесших инсульт: 59 пациентам группы 1 (сравнения) проводили стандартную программу реабилитации; 63 пациентам группы 2 (основной) - разработанную программу социальной реабилитации. Изучено динамическое состояние пациентов по показателям шкал оценки функционального, когнитивного, психоэмоционального статуса и социальной активности в течение полугода. У пациентов группы 2 через 6 месяцев после начала наблюдения отмечена более выраженная (относительно группы сравнения) динамика изучаемых показателей, что подтвердили статистически значимо более высокие значения показателей шкал Ривермид $(p=0,011)$ и SS-QOL $(p<0,05)$ и более низкие значения показателей шкал DASH и шкалы Бека $(p=0,015$ и p < 0,001 соответственно). В обеих группах выявлено некоторое увеличение показателей шкалы оценки когнитивных нарушений MMSE, однако значимых межгрупповых различий при этом не отмечено. Разработанная программа медицинской реабилитации пациентов, перенесших ОНМК, эффективна для восстановления навыков самообслуживания, восстановления социально значимых навыков, таких как социально-бытовая адаптация. Использованные в работе шкалы и опросники чувствительны к изменениям функционального статуса пациентов с постинсультными нарушениями средней степени тяжести, в первую очередь - шкалы DASH и SS-QOL.
\end{abstract}

Ключевые слова: инсульт, реабилитация, социальная оценка, когнитивный статус, физическая активность, неврологический статус, качество жизни

Вклад авторов: В. В. Храмов - планирование исследования, подготовка и редактирование рукописи; К. П. Когаева - планирование и проведение научных исследований, подготовка и редактирование рукописи; Л. Ю. Архипова - обзор литературы, интерпретация данных; В. О. Алексеева, М. И. Лукьянова - статистический анализ.

Соблюдение этических стандартов: исследование одобрено этическим комитетом Саратовского ГМУ имени В. И. Разумовского (протокол № 1 от 1 сентября 2020 г.); все участники подписали добровольное информированное согласие на участие в исследовании.

Для корреспонденции: Ксения Павловна Когаева ул. Красная, д. 69, г. Камышин, 403873; drkogan100@mail.ru

Статья получена: 25.02.2021 Статья принята к печати: 18.03.2021 Опубликована онлайн: 31.03.2021

DOI: $10.24075 /$ vrgmu.2021.012

Stroke is among the leading causes of morbidity and long-term disability in high-income countries. In Russia, the incidence of stroke is 3-4 cases per 1,000 population. Survival has improved to $85 \%$ in the past few years; currently, there are over $1,000,000$ stroke survivors living in Russia, of whom 80 percent are disabled. So, post-stroke rehabilitation is becoming increasingly important for economy and society [1-6].

Stroke is a life-changing event both at the individual and community levels. Its sequelae prevent the patient from returning to work, lead to social isolation and are a heavy burden for economy $[3,5,7,8]$.

It is known that stroke can have a long-lasting impact on personal, familial and social well-being that persists after primary rehabilitation. Patients and their caregivers need access to rehabilitation resources and services [9-14]. Medical and social care is provided by healthcare specialists, social workers and volunteers [7, 8]. Highly-skilled medical professionals provide effective care in the early rehabilitation period. Then, 
other rehabilitation specialists step in to assist patients in social adaptation and relearning self-care skills.

What is known about the needs of stroke survivors and their caregivers is usually known from clinical data and observational studies which analyze a number of parameters using mostly non-standardized methods. That said, such data are sufficient to highlight some important problems, including social and emotional consequences of stroke that persist for many years after the initial event [15-20].

Considering the recent initiatives of public health agencies aimed at fighting the effects of stroke on individual and public health, it would be interesting to analyze the outcomes of social rehabilitation programs for stroke survivors through the medical and social lens and to estimate the sensitivity of the methods used to assess the functional state of stroke patients.

The aim of this study was to demonstrate the effectiveness of standardized post-stroke rehabilitation for patients with moderate impairments.

\section{METHODS}

This prospective randomized controlled parallel-group study was conducted at Kamyshin City Hospital № 1, Volgograd region, between 2016 and 2020. The study enrolled 122 stroke survivors with moderate impairments: 71 women $(58.2 \%)$ and 51 men (41.8\%). The mean age of the participants was $66.5 \pm$ 12.8 years.

The following inclusion criteria were applied: both sexes, age between 18 and 85 years, moderate stroke within 6 previous months. Patients with severe stroke, brain tumors, somatic pathology, or psychiatric disorders were excluded from the study.

The patients were divided into 2 groups based on the type of rehabilitation program:

- group 1 (the comparison group) consisted of 59 patients undergoing standard rehabilitation;

- group 2 (the main group) consisted of 63 patients participating in the rehabilitation program proposed by the authors of this paper.

Patients included in the study were moderate stroke survivors in the late rehabilitation period. The average NIHSS score was 11.75 points. During the study, both groups received 10 sessions of physical exercise, 10 sessions of massage, 10 sessions of physiotherapy, 2 sessions of occupational therapy, and 1 session of social adaptation. Additionally, the main group received 5 sessions of occupational therapy, 5 sessions of social adaptation and 5 sessions of self-care skills.

Progress was evaluated using assessment scales for measuring functional, cognitive, psychoemotional status and social activity. Assessments were made before rehabilitation, after discharge from the hospital, i.e. 12-14 days after admission, and then at 1,3 and 6 months.

Before rehabilitation, all patients underwent a medical checkup and a neurological examination. The following assessment tools were used in the study: the Barthel Index, the Rivermead Mobility Index, the DASH questionnaire, the Beck Depression Inventory, the MMSE questionnaire, and the SS-QoL score (Stroke Specific Quality of Life).

\section{Social and medical rehabilitation of stroke survivors}

For the purpose of this study, we designed a social rehabilitation program for stroke survivors. Unlike standard rehabilitation, the amount and type of interventions included in our program varied depending on the stroke sequelae experienced by the patient. The program was designed to fulfill the needs of stroke survivors with moderate impairments. The rehabilitation plan included social adaptation sessions conducted once a month, followed by the analysis of goal achievements. During the session, the patients were tested using the assessment tools listed above. Once every 2 weeks, we called the patients on the phone to check their adherence to the program and modify the tasks if necessary.

Each patient received a detailed written description of the rehabilitation program, with a daily planner for ticking the tasks performed during the day. The following skills were trained: using the bathroom and doing morning hygiene (independently, daily), taking a bath with minimal assistance, getting dressed with minimal assistance, doing up the buttons, tying shoelaces (independently). As part of their rehabilitation, the patients were asked to do simple cooking (make a sandwich or fried eggs) or try more challenging dishes (salad, soup) and do the dishwashing.

Physical activities included in the rehabilitation program were as follows: indoor walking over 200 m, going up and down the stairs, taking a walk outside, doing easy chores (bed making, dusting) or more difficult chores (mopping), gardening,

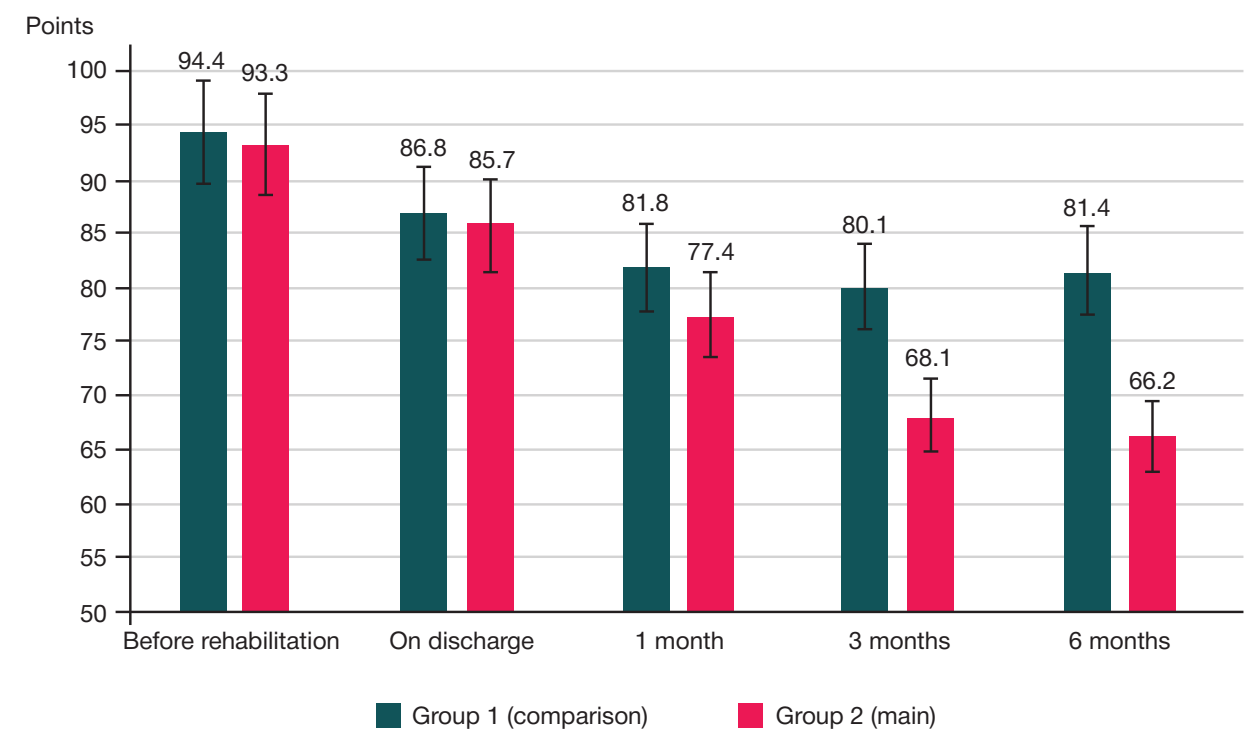

Fig. 1. Dynamics of the Barthel Index, $M \pm m$ 


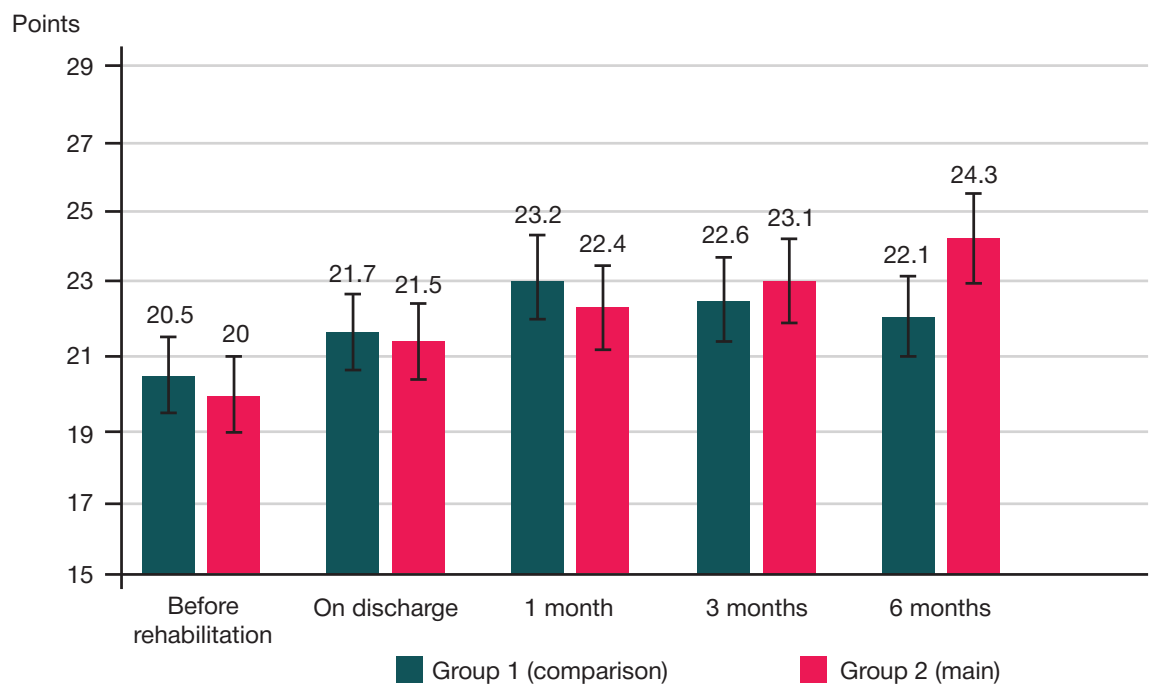

Fig. 2. Dynamics of the Rivermead Mobility Index, $M \pm m$

taking care of indoor plants. Social activities included in the program were as follows: visiting family and friends, going to the cinema or theater, and hobbies (drawing, playing chess). We called the patients twice a month to evaluate their progress.

Statistical analysis was carried out in STATISTICA 10 (Statsoft; USA). Mean values and the standard error of the mean were calculated for quantitative parameters. Intergroup comparisons were done using the nonparametric MannWhitney $U$ test, accounting for the specific character of the analyzed parameters. Differences were considered significant at $p>0.05$.

\section{RESULTS}

The Barthel Index (independence) measured immediately after hospital treatment was higher than on admission. However, there were no significant differences between the groups: $72.7 \pm 4.1$ vs $72.1 \pm 5.5$ points for groups 1 and 2 , respectively. $\mathrm{Bl}$ dynamics were positive in both groups after discharge home and at 1, 3, and 6 months, with no significant difference between the groups (Fig. 1). Before rehabilitation, the NIHSS score was $11.4 \pm 4.0$ in group 1 and $12.1 \pm 5.0$ points in group 2, with no significant difference between the groups.

Three months after the rehabilitation program was commenced, the Rivermead Mobility Index increased to
$8.4 \pm 0.4$ in the main group ( $p=0.011)$; at 6 months, it was $8.4 \pm 0.5$ (Fig. 2). At both time points, the main group scored significantly higher than the comparison group $(p<0.05)$.

At 3 months, the DASH score declined to $68.1 \pm 2.9$ points in the main group and was statistically lower $(p<0.001)$ than in the comparison group $(80.1 \pm 5.2)$. At 6 months, the situation was the same: $81.4 \pm 6.4$ points in group 1 vs $66.2 \pm 3.1$ points in group 2 ( $p=0.015$ ) (Fig. 3).

In the comparison group, the Beck Depression Inventory score declined to $15.3 \pm 1.8$ points at 3 months. The score was significantly lower in the main group $(p=0.008)$, equaling $12.7 \pm 1.6$ points. At 6 months, the situation was the same: group 1 scored $15.8 \pm 1.4$ points, group 2 scored $13.1 \pm 0.9$ points $(p<0.001)$ (Fig. 4).

Before rehabilitation, the total MMSE (cognition) score was $20.5 \pm 1.5$ points in group 1 vs $20.0 \pm 1.8$ points in group 2 . During the follow-up period, this parameter was slightly increasing slightly, with no significant difference between the groups (Fig. 5).

Before rehabilitation, both groups were comparable in terms of all SS-QoL (quality of life) domain scores (Table). At 6 months, the main group scored higher on most domains than the comparison group. For example, group 1 scored an average of $2.60 \pm 0.17$ points on the "energy" domain, whereas group 2 scored $3.07 \pm 0.15$ points, which was a significantly higher value $(p<0.05)$. The main group scored significantly

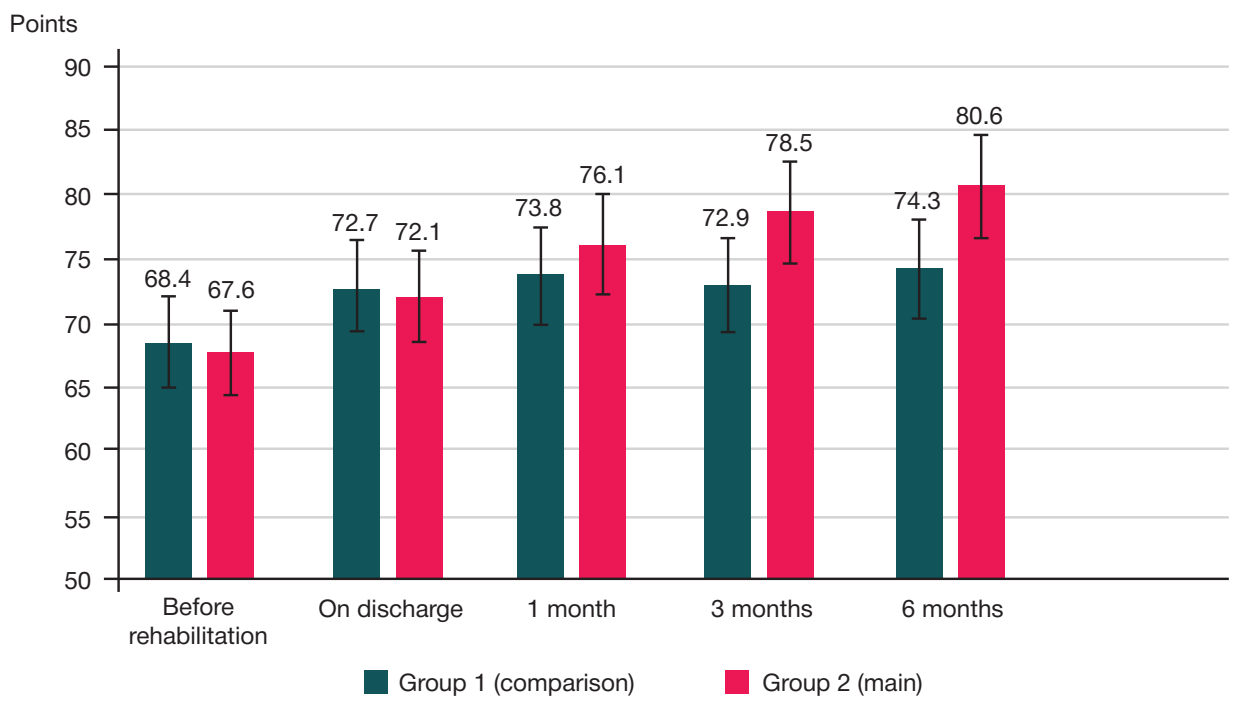

Fig. 3. Dynamics of DASH scores, $\mathrm{M} \pm m$ 


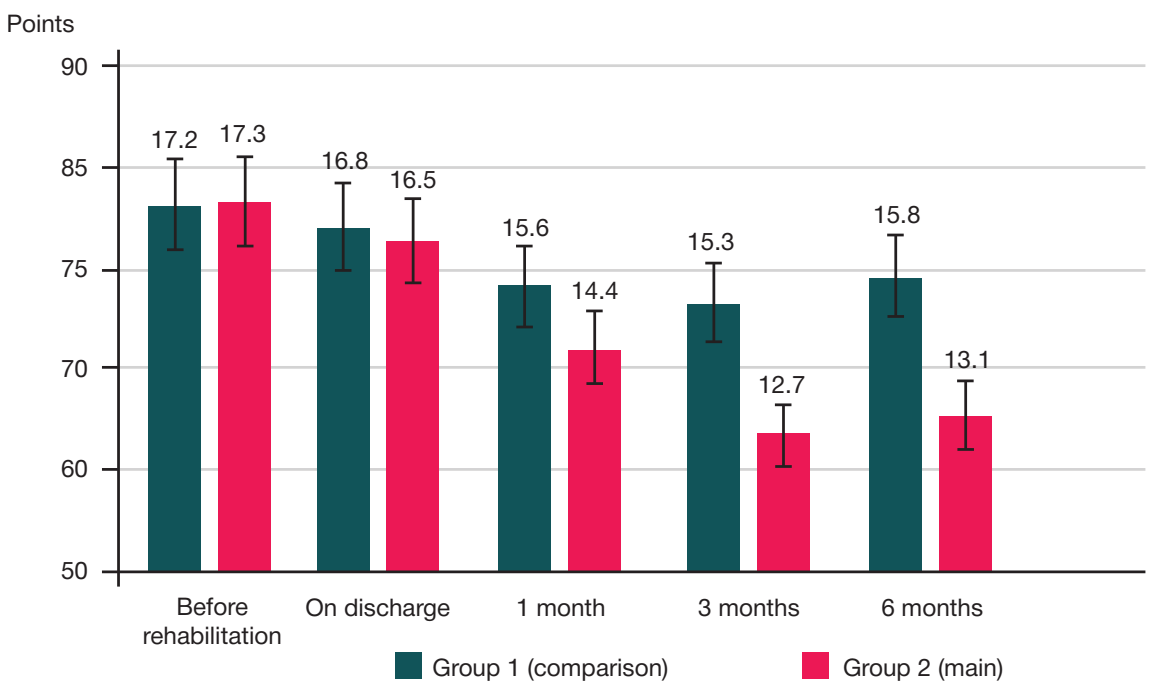

Fig. 4. Dynamics of Beck Depression Inventory scores, $M \pm m$

higher on the "family roles" domain than the comparison group, but the "language" score did not differ significantly between the groups. The "mobility" score was significantly higher in group 2 than in group 1 ( $4.31 \pm 0.29$ vs $2.92 \pm 0.37$ points; $p<0.05)$.

The following scores were significantly higher in the main group than in the comparison group $(p<0.05)$ : $\operatorname{mood}(4.34 \pm 0.41$ vs $2.85 \pm 0.28)$, self-care ( $4.70 \pm 0.19$ vs $3.82 \pm 0.20)$, social roles $(3.82 \pm 0.25$ vs $2.74 \pm 0.17)$, work, productivity $(3.20 \pm 0.28$ vs $2.41 \pm 0.15)$, upper extremity function (4.03 \pm 0.19 vs $4.74 \pm 0.21$.

Vision, thinking and personality scores did not change in comparison with the baseline values in both groups.

The analysis shows that the proposed rehabilitation program was effective in helping stroke survivors recover important social skills: families started paying more attention to their stroke-affected members, patients became less dependent on their families. Repetitive self-care training makes the patient more active, reduces functional dependency on family members, and restores the patient's role in the family. Regular meetups with friends and social activities improve social integration. As part of the rehabilitation program, we spoke with our patients on the phone once every two weeks over the course of 6 months and had social adaptation sessions once a month, which allowed us to control adherence to the program and task performance (going for a walk, meeting friends, gardening, hobbies). Regular control and active involvement of relatives in rehabilitation improved social activity of the patients indicated by increased SS-Qol scores.

At 6 months, the dynamics of the studied parameters were more pronounced in the main group than in the comparison group, as seen from the significantly higher Rivermead Mobility Index, higher SS-QoL scores and lower DASH and Beck scores.

\section{DISCUSSION}

Today, most experts hold the opinion that recovery of functions affected by the stroke, adaptation to the loss of such functions and social integration should be a top-priority in the rehabilitation of stroke survivors [20-23]. Therefore, it is essential to understand the needs of stroke survivors and challenges they face in order to develop effective approaches involving high-quality medical care and social work services [24-27]. When evaluating the quality of care, it is important to receive a feedback from the patient and their caregiver about the quality of care and to clarify what could be improved.

Our findings are consistent with the results of other studies reporting the mitigating effect of social work services on stress levels and the consequences of stress in stroke

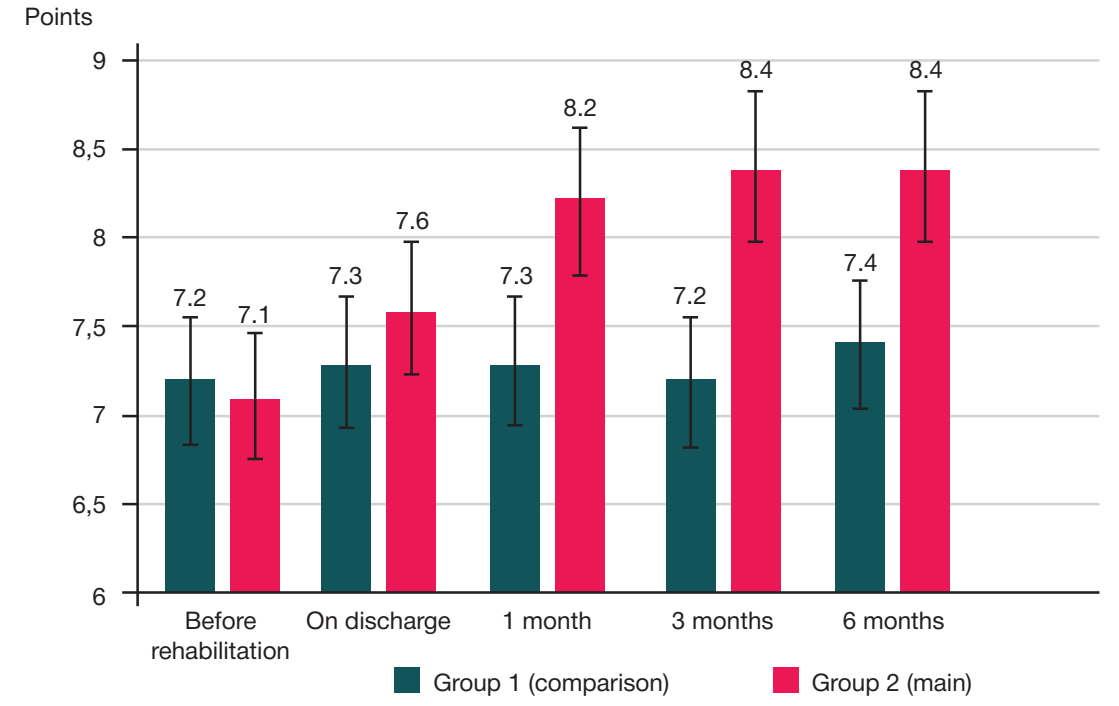

Fig. 5. Dynamics of the total MMSE score, $\mathrm{M} \pm m$ 


\begin{tabular}{|c|c|c|c|c|}
\hline & \multicolumn{2}{|c|}{ Before rehabilitation } & \multicolumn{2}{|c|}{ At 6 months } \\
\hline & $\begin{array}{c}\text { Group } 1 \\
\text { (comparison) }\end{array}$ & $\begin{array}{l}\text { Group } 2 \\
\text { (main) }\end{array}$ & $\begin{array}{c}\text { Group } 1 \\
\text { (comparison) }\end{array}$ & $\begin{array}{l}\text { Group } 2 \\
\text { (main) }\end{array}$ \\
\hline Energy & $2.72 \pm 0.22$ & $2.63 \pm 0.24$ & $2.60 \pm 0.17$ & $3.07 \pm 0.15^{*}$ \\
\hline Family roles & $2.66 \pm 0.32$ & $2.62 \pm 0.18$ & $2.43 \pm 0.21$ & $3.72 \pm 0.32^{*}$ \\
\hline Language & $3.91 \pm 0.19$ & $3.85 \pm 0.26$ & $3.81 \pm 0.16$ & $3.74 \pm 0.26$ \\
\hline Mobility & $3.30 \pm 0.35$ & $3.56 \pm 0.23$ & $2.92 \pm 0.37$ & $4.31 \pm 0.29^{*}$ \\
\hline Mood & $3.21 \pm 0.21$ & $3.42 \pm 0.40$ & $2.85 \pm 0.28$ & $4.34 \pm 0.41^{*}$ \\
\hline Personality & $3.24 \pm 0.17$ & $3.31 \pm 0.31$ & $3.13 \pm 0.32$ & $3.32 \pm 0.22$ \\
\hline Self-care & $4.07 \pm 0.42$ & $4.24 \pm 0.25$ & $3.82 \pm 0.20$ & $4.70 \pm 0.19^{*}$ \\
\hline Social roles & $3.09 \pm 0.33$ & $2.80 \pm 0.17$ & $2.74 \pm 0.17$ & $3.82 \pm 0.25^{*}$ \\
\hline Thinking & $2.62 \pm 0.27$ & $2.63 \pm 0.15$ & $2.51 \pm 0.24$ & $2.61 \pm 0.16$ \\
\hline Upper extremity function & $4.35 \pm 0.21$ & $4.52 \pm 0.14$ & $4.03 \pm 0.19$ & $4.74 \pm 0.21^{*}$ \\
\hline Vision & $2.93 \pm 0.12$ & $3.05 \pm 0.22$ & $2.72 \pm 0.21$ & $2.92 \pm 0.15$ \\
\hline Work, productivity & $2.51 \pm 0.17$ & $2.62 \pm 0.26$ & $2.41 \pm 0.15$ & $3.20 \pm 0.28^{*}$ \\
\hline
\end{tabular}

Note: ${ }^{*}$ - differences are significant $(p<0.05)$ relative to the comparison group ( the Mann-Whitney $U$ test).

survivors [25, 26]. In spite of almost zero gains in functional independence, participation of stroke survivors in social activities increases their subjective satisfaction and quality of life $[27,28]$.

Effective post-stroke rehabilitation requires a multifaceted multidisciplinary approach. According to the literature, rehabilitation is more effective when the patient's experience and feedback are taken into account. Active participation of the patient is important for establishing positive relationship between the patient and the therapist and for ensuring that there is no breach of ethics, especially in patient-oriented rehabilitation programs $[26,28]$.

In Russia, many rehabilitation facilities for neurology patients provide social rehabilitation services. They offer complex rehabilitation programs for the disabled that include social integration; this improves social adaptation, allows them to take vocational training and find a new job [14, 21].

\section{References}

1. Gurov AN, Katunceva NA. Uroven' zabolevaemosti cerebrovaskuljarnymi boleznjami, letal'nosti i smertnosti v Moskovskoj oblasti v 2014 g. Al'manah klinicheskoj mediciny. 2015; 39: 11-14. Russian.

2. Luker J, Lynch E, Bernhardsson S, Bennett L, Bernhardt J. Stroke survivors' experiences of physical rehabilitation. A systematic review of qualitative studies. Arch Phys Med Rehabil. 2015; 96: 1698-708. DOI: 10.1016/j.apmr.2015.03.017.

3. Patel A, Berdunov V, Quayyum Z, King D, Knapp M, Wittenberg R. Estimated societal costs of stroke in the UK based on a discrete event simulation. Age Ageing. 2020; 49 (2): 270-276. DOI: 10.1093/ageing/afz162.

4. Polunina NV, Kostenko EV, Polunin VS. Mediko-social'naja jeffektivnost' reabilitacii $v$ ambulatornyh uslovijah pacientov, perenesshih mozgovoj insul't. Problemy social'noj gigieny, zdravoohranenija i istorii mediciny. 2017; 25 (6): 353-356.DOl: 10.18821/0869-866X-2016-25-6-353-356. Russian.

5. Erler KS, Sullivan V, Mckinnon S, Inzana R. Social Support as a Predictor of Community Participation After Stroke. Front Neurol. 2019; 10: 1013. DOI: 10.3389/fneur.2019.01013. e

6. MMiryutova NF, Vorobev VA, Minchenko NN, Samojlova IM, Zajcev AA, Mareeva LV, i dr. Integral'naja ocenka narushenij zdorov'ja i jeffektivnosti jetapnoj reabilitacii bol'nyh posle

\section{CONCLUSIONS}

The standardized program for medical and social rehabilitation of stroke survivors with moderate impairments was effective in terms of its clinical, psychological and social outcomes. The scales and inventories used in the study (specifically the Rivermead Mobility Index, DASH and the SS-QOL questionnaire) are sensitive to changes in the functional state of stroke patients with moderate impairments. More initiatives are needed to raise awareness and provide consultations on post-stroke adaptation, organize social, cultural, sports and educational events. It is important to conduct studies that provide the rationale for and refine the systemic approach to planning and implementing social support services for stroke survivors. Using such approaches in rehabilitation practice will increase the level of social support for stroke survivors, help them to recover the affected functions, encourage patients to actively participate in social activities and thus improve patient outcomes. ishemicheskogo insul'ta. Voprosy kurortologii, fizioterapii i lechebnoj fizicheskoj kul'tury. 2019; 96 (6): 5. DOl: 10.17116/ kurort2019960615. Russian.

7. Schindel D, Schneider A, Grittner U, Jöbges M, Schenk L. Quality of life after stroke rehabilitation discharge: a 12-month longitudinal study. Disabil Rehabil. 2019; Dec 17. DOl: 10.1080/09638288.2019.1699173.

8. Cai Y, Towne SD, Bickel CS. Multi-Level Factors Associated with Social Participation among Stroke Survivors: China's Health and Retirement Longitudinal Study (2011-2015). Int J Environ Res Public Health. 2019; 16 (24): E5121. DOI: 10.3390/ ijerph16245121.

9. Memetov SS, Sharkunov NP, Cheprakova JeV, Kim W. Nekotorye osobennosti mediko-social'noj reabilitacii lic, perenesshih ostroe narushenie mozgovogo krovoobrashhenija, na municipal'nom urovne. Vestnik Vserossijskogo obshhestva specialistov po mediko-social'noj jekspertize, reabilitacii i reabilitacionnoj industrii. 2019; 3: 92-100. DOI: 10.17238/issn1999-2351.2019.3.92-100. Russian.

10. Tashiro H, Isho T, Takeda T, Nakamura T, Kozuka N, Hoshi F. Utility of Dynamic Balance Measurements in Discriminating Community Ambulation Levels Among Individuals with Stroke: A Crosssectional Study. J Stroke Cerebrovasc Dis. 2020; 29 (4): 104603. 
DOI: 10.1016/j.jstrokecerebrovasdis.2019.104603.

11. Pedersen SG, Friborg O, Heiberg GA, Arntzen C, Stabel HH, Thrane G, et al. Stroke-Specific Quality of Life one-year poststroke in two Scandinavian country-regions with different organisation of rehabilitation services: a prospective study. Disabil Rehabil. 2020. May 1. DOI: 10.1080/09638288.2020.1753830. Epub ahead of print.

12. Nazmetdinova DG, Obuhovskaja VB. Osobennosti kognitivnoj i jemocional'no-volevoj sfer pacientov s postinsul'tnymi nevrologicheskimi narushenijami na raznyh jetapah vosstanovitel'nogo lechenija. Psiholog. 2020; 1: 9-15. DOI: 10.25136/2409-8701.2020.1.31680. Russian.

13. Verberne DPJ, Post MWM, Köhler S, Carey LM, Visser-Meily JMA, van Heugten CM. Course of Social Participation in the First 2 Years After Stroke and Its Associations With Demographic and Stroke-Related Factors. Neurorehabil. Neural Repair. 2018; 32 (9): 821-33. DOI: 10.1177/1545968318796341.

14. Kosivcova OV. Vedenie pacientov $\vee$ vosstanovitel'nom periode insul'ta. Nevrologija, nejropsihiatrija, psihosomatika. 2014; 4: 1015. DOI: 10.14412/2074-2711-2014-4-101-105. Russian.

15. Cherdak MA, Yahno NN. Postinsul'tnye kognitivnye rasstrojstva. Zhurnal Nevrologiii im. B.M. Man'kovs'kogo. 2013; 1: 31. Russian.

16. Stiekema APM, Nijsse B, de Kort PLM, Spikman JM, Visser-Meily JMA, van Heugten CM. The relationship between social cognition and participation in the long term after stroke. Neuropsychol Rehabil. 2019; 19: 1-15. DOI: 10.1080/09602011.2019.1692670.

17. Zhang WW, Speare S, Churilov L. Stroke rehabilitation in China: a systematic review and meta-analysis. Int J Stroke. 2013; 112: 846-55. DOI: 10.1111/ijs.12029.

18. Mohd Nordin NA, Aziz NA, Abdul Aziz AF, Ajit Singh DK, Omar Othman NA, Sulong $S$, et al. Exploring views on longterm rehabilitation for people with stroke in a developing country: findings from focus group discussions. BMC Health Serv Res. 2014; 14: 118. DOI: 10.1186/1472-6963-14-118.

19. Zhang $H$, Qian $H Z$, Meng $S Q$, Shu M, Gao YZ, Xu Y, et al. Psychological distress, social support and medication adherence in patients with ischemic stroke in the mainland of China. J
Huazhong Univ Sci Technolog Med Sci. 2015; 35 (3): 405-10. DOI: 10.1007/s11596-015-1445-y.

20. Turner-Stokes L, Rose H, Ashford S, Singer B. Patient engagement and satisfaction with goal planning: Impact on outcome from rehabilitation. International Journal of Therapy and Rehabilitation. 2015; 22: 210-216.

21. Zima YuV, Markin NN. Fizicheskaja reabilitacija insul'tnyh bol'nyh na rannih jetapah vosstanovlenija. Sovremennye napravlenija razvitija sistemy fizkul'turnogo i tehnologicheskogo obrazovanija. Saratov, 2016: 142-5.

22. Linder S, Rosenfeldt A, Rasanow M, Alberts J. Forced Aerobic Exercise Enhances Motor Recovery After Stroke: A Case Report. Am J Occup Ther. 2015; 69 (4): 1-8. DOI: 10.5014/ ajot.2015.015636.

23. Satink T, Cup EH, llott I, Prins J, de Swart BJ, Nijhuis-van der Sanden MW. Patients' Views on the impact of stroke on their roles and self: A thematic synthesis of qualitative studies. Arch Phys Med Rehabil. 2013; 94: 1171-83. DOI: 10.1016/j.apmr.2013.01.011.

24. Constand MK, MacDermid JC, Bello-Haas VD, Law M. Scoping review of patient-centered care approaches in healthcare. BMC Health Serv Res. 2014; 14: 271. DOI: 10.1186/1472-6963-14-271.

25. Herisson F, Godard S, Volteau C, Le Blanc E, Guillon B, Gaudron M. Early Sitting in Ischemic Stroke Patients (SEVEL): A Randomized Controlled Trial. PLoS One. 2016; 11(3): e0149466. DOI: 10.1371/journal.pone.0149466.

26. Singam A, Ytterberg C, Tham K, von Koch L. Participation in Complex and Social Everyday Activities Six Years after Stroke: Predictors for Return to Pre-Stroke Level. PLoS One. 2015; Dec 10; 10 (12): e0144.

27. Kristensen HK, Tistad M, Koch Lv, Ytterberg C. The Importance of Patient Involvement in Stroke Rehabilitation. PLOS ONE. 2016; 11 (6): e0157149. DOI: 10.1371/journal.pone.0157149.

28. Smith AJ, Campbell RW, Harrison PK, Harrison DW. Functional cerebral space theory: Towards an integration of theory and mechanisms of left hemineglect, anosognosia, and anosodiaphoria. NeuroRehabilitation. 2016; 38 (2): 147-154. DOI: 10.3233/NRE-161304.

\section{Литература}

1. Гуров А. Н., Катунцева Н. А. Уровень заболеваемости цереброваскулярными болезнями, летальности и смертности в Московской области в 2014 г. Альманах клинической медицины. 2015; 39: 11-14.

2. Luker J, Lynch E, Bernhardsson S, Bennett L, Bernhardt J. Stroke survivors' experiences of physical rehabilitation. A systematic review of qualitative studies. Arch Phys Med Rehabil. 2015; 96: 1698-708. DOI: 10.1016/j.apmr.2015.03.017.

3. Patel A, Berdunov V, Quayyum Z, King D, Knapp M, Wittenberg R. Estimated societal costs of stroke in the UK based on a discrete event simulation. Age Ageing. 2020; 49 (2): 270-276. DOl: 10.1093/ageing/afz162.

4. Полунина Н. В., Костенко Е. В., Полунин В. С. Медикосоциальная эффективность реабилитации в амбулаторных условиях пациентов, перенесших мозговой инсульт. Проблемы социальной гигиены, здравоохранения и истории медицины. 2017; 25 (6): 353-356.DOI: 10.18821/0869-866X2016-25-6-353-356.

5. Erler KS, Sullivan V, Mckinnon S, Inzana R. Social Support as a Predictor of Community Participation After Stroke. Front Neurol. 2019; 10: 1013. DOI: 10.3389/fneur.2019.01013. e

6. Мирютова Н. Ф., Воробьев В. А., Минченко Н. Н., Самойлова И. М., Зайцев А. А., Мареева Л. В. и др. Интегральная оценка нарушений здоровья и эффективности этапной реабилитации больных после ишемического инсульта. Вопросы курортологии физиотерапии и лечебной физической культуры. 2019; 96 (6): 5. DOI: 10.17116/kurort2019960615.

7. Schindel D, Schneider A, Grittner U, Jöbges M, Schenk L. Quality of life after stroke rehabilitation discharge: a 12-month longitudinal study. Disabil Rehabil. 2019; Dec 17. DOI: 10.1080/09638288.2019.1699173.

8. Cai Y, Towne SD, Bickel CS. Multi-Level Factors Associated with Social Participation among Stroke Survivors: China's Health and Retirement Longitudinal Study (2011-2015). Int J Environ Res Public Health. 2019; 16 (24): E5121. DOI: 10.3390/ ijerph16245121.

9. Меметов С. С., Шаркунов Н. П., Чепракова Э. В., Ким В. В. Некоторые особенности медико-социальной реабилитации лиц, перенесших острое нарушение мозгового кровообращения, на муниципальном уровне. Вестник Всероссийского общества специалистов по медико-социальной экспертизе, реабилитации и реабилитационной индустрии. 2019; 3: 92100. DOI: 10.17238/issn1999-2351.2019.3.92-100.

10. Tashiro H, Isho T, Takeda T, Nakamura T, Kozuka N, Hoshi F. Utility of Dynamic Balance Measurements in Discriminating Community Ambulation Levels Among Individuals with Stroke: A Crosssectional Study. J Stroke Cerebrovasc Dis. 2020; 29 (4): 104603. DOI: 10.1016/j.jstrokecerebrovasdis.2019.104603.

11. Pedersen SG, Friborg O, Heiberg GA, Arntzen C, Stabel HH, Thrane G, et al. Stroke-Specific Quality of Life one-year poststroke in two Scandinavian country-regions with different organisation of rehabilitation services: a prospective study. Disabil Rehabil. 2020. May 1. DOI: 10.1080/09638288.2020.1753830. Epub ahead of print.

12. Назметдинова Д. Г., Обуховская В. Б. Особенности когнитивной и эмоционально-волевой сфер пациентов с постинсультными неврологическими нарушениями на разных этапах восстановительного лечения. Психолог. 2020; 1: 9-15. DOI: 10.25136/2409-8701.2020.1.31680

13. Verberne DPJ, Post MWM, Köhler S, Carey LM, Visser-Meily JMA, van Heugten CM. Course of Social Participation in the First 2 Years After Stroke and Its Associations With Demographic and 
Stroke-Related Factors. Neurorehabil. Neural Repair. 2018; 32 (9): 821-33. DOI: 10.1177/1545968318796341.

14. Косивцова О. В. Ведение пациентов в восстановительном периоде инсульта. Неврология, нейропсихиатрия, психосоматика. 2014; 4: 101-5. DOI: 10.14412/2074-2711-2014-4-101-105

15. Чердак М. А., Яхно Н. Н. Постинсультные когнитивные расстройства. Журнал Неврології ім. Б.М. Маньковського. 2013; $1: 31$.

16. Stiekema APM, Nijsse B, de Kort PLM, Spikman JM, Visser-Meily JMA, van Heugten CM. The relationship between social cognition and participation in the long term after stroke. Neuropsychol Rehabil. 2019; 19:1-15. DOI: 10.1080/09602011.2019.1692670.

17. Zhang WW, Speare S, Churilov L. Stroke rehabilitation in China: a systematic review and meta-analysis. Int J Stroke. 2013; 112: 846-55. DOI: 10.1111/ijs.12029.

18. Mohd Nordin NA, Aziz NA, Abdul Aziz AF, Ajit Singh DK, Omar Othman NA, Sulong $S$, et al. Exploring views on longterm rehabilitation for people with stroke in a developing country: findings from focus group discussions. BMC Health Serv Res. 2014; 14: 118. DOI: 10.1186/1472-6963-14-118.

19. Zhang $H$, Qian $H Z$, Meng $S Q$, Shu M, Gao $Y Z, X u Y$, et al. Psychological distress, social support and medication adherence in patients with ischemic stroke in the mainland of China. $J$ Huazhong Univ Sci Technolog Med Sci. 2015; 35 (3): 405-10. DOI: 10.1007/s11596-015-1445-y.

20. Turner-Stokes L, Rose H, Ashford S, Singer B. Patient engagement and satisfaction with goal planning: Impact on outcome from rehabilitation. International Journal of Therapy and Rehabilitation. 2015; 22: 210-216.

21. Зима Ю. В., Маркин Н. Н. Физическая реабилитация инсультных больных на ранних этапах восстановления. Современные направления развития системы физкультурного и технологического образования. Саратов, 2016: 142-5.

22. Linder S, Rosenfeldt A, Rasanow M, Alberts J. Forced Aerobic Exercise Enhances Motor Recovery After Stroke: A Case Report. Am J Occup Ther. 2015; 69 (4): 1-8. DOI: 10.5014/ ajot.2015.015636.

23. Satink T, Cup EH, llott I, Prins J, de Swart BJ, Nijhuis-van der Sanden MW. Patients' Views on the impact of stroke on their roles and self: A thematic synthesis of qualitative studies. Arch Phys Med Rehabil. 2013; 94: 1171-83. DOI: 10.1016/j.apmr.2013.01.011.

24. Constand MK, MacDermid JC, Bello-Haas VD, Law M. Scoping review of patient-centered care approaches in healthcare. BMC Health Serv Res. 2014; 14: 271. DOI: 10.1186/1472-6963-14-271.

25. Herisson F, Godard S, Volteau C, Le Blanc E, Guillon B, Gaudron M. Early Sitting in Ischemic Stroke Patients (SEVEL): A Randomized Controlled Trial. PLoS One. 2016; 11(3): e0149466. DOI: 10.1371/journal.pone.0149466.

26. Singam A, Ytterberg $C$, Tham $K$, von Koch L. Participation in Complex and Social Everyday Activities Six Years after Stroke: Predictors for Return to Pre-Stroke Level. PLoS One. 2015; Dec 10; 10 (12): e0144.

27. Kristensen HK, Tistad M, Koch Lv, Ytterberg C. The Importance of Patient Involvement in Stroke Rehabilitation. PLOS ONE. 2016; 11 (6): e0157149. DOI: 10.1371/journal.pone.0157149.

28. Smith AJ, Campbell RW, Harrison PK, Harrison DW. Functional cerebral space theory: Towards an integration of theory and mechanisms of left hemineglect, anosognosia, and anosodiaphoria. NeuroRehabilitation. 2016; 38 (2): 147-154. DOI: 10.3233/NRE-161304. 